Bull. Fac. Agric., Cairo Univ., 59 (2008): 301-305.

\title{
A STUDY ON FLORAL BIOLOGY, POLLINATION AND FRUIT SET OF TWO OLIVE CULTIVARS IN SOUTH JORDAN
}

(Received: 10. 4. 2008)

\author{
By \\ A. A. Al-Joumayly and R. L. Ahmad \\ Department of Plant Production, Faculty of Agriculture, Mu'tah University, Mu'tah, Al-Karak, Jordan \\ * National Center for Agricultural Research and Extension, Amman, Jordan
}

\begin{abstract}
Floral characteristics, pollination and fruit set were investigated on two olive cultivars grown under rain fed conditions in South Jordan during 2002 and 2003 seasons. Nabali Muhassan and Grossa de spagan cultivars did not differ significantly in production of perfect flowers, and in pollen grain germination value in the two seasons, while Nabali Muhassan produced higher pollen grains number than Grossa de spagan. The highest percentage of fruit set occurred from open pollination, while self pollination for the two cultivars resulted in the lowest fruit set with the highest shotberries percentage for the two cultivars. However, hand cross pollination between these two cultivars was not efficient to improve the fruit set percentage.
\end{abstract}

Key words: fruit set, olives, perfect flowers, pollen grains.

\section{INTRODUCTION}

Increasing of plantation areas for any fruit kind or cultivar depends on suitable environmental factors and its ability to fruit set. Pollination is the first step for fruit set and seed development in fruits known as drupes, in which olive (Olea europaea) is one of them. Some olive cultivars are classified as self-sterile (self-incompatible), others are self-fertile and partially self-fertile (FAO, 2000). The flower structure plays a very important role in the former classification, olive trees are known as andromonoecious (Cuevas et al., 1999). It depends on the cultivar and environmental conditions, trees may have staminate flowers at the same inflorescence (Badr and Hartmann, 1971). Ateyyeh et al. (2000) reported that there are staminate, flowers normal perfect and perfect with aborted pistil. The percentage of perfect flower differs according to many factors such as cultivar, growing season, leaf to bud ratio, nutritional status, water stress during inflorescence development and vegetative vigor (Noro, 1926, Brooks, 1948, Uriu, 1959, Hartmann and Panetssos, 1961 and Shatat and Sawwan, 1986). Many olive cultivars are self-incompatible, pollinizer planting with their trees is necessary for fruit set (Ugrinovic and Stamper, 1996, Cuevas and Polito, 1997, Iannott et al., 1999). The productivity of partially self-fertile and even for self-fertile olive cultivars can be improved by cross pollination. Many researchers indicated that open pollination and controlled cross pollination increased fruit yield and improved their quality for many different cultivars (Lavee and Datt, 1978, Fernandez-Escobar and Gomez-Valledor, 1985, Cuevas and Rallo, 1990, Salman, 1992, Hechimi and Raoudha, 1995, Daoud, 1997, Ateyyeh et al., 2000 and Al-Kasasbeh, 2003). The occurrence of shotberries was reduced by cross pollination and in turn improved fruit yield and quality compared to self pollination (Lavee and Datt, 1978 and Rapoport and Rallo, 1990).

The objectives of this investigation were to study some floral characteristics of two olive cultivars Nabali Muhassan and Grossa de Spagan to examine the self-compatibility, and the effect of self and cross-pollination on fruit set of these cultivars.

\section{MATERIALS AND METHODS}

Six single productive trees of each of two olive cultivars (Nabali Muhassan and Grossa de Spagan) were chosen at the National Center for Agricultural Research and Technology Transfer at Al-Rabbaa Station during 2002 and 2003 seasons. Experiment was consisting mainly of three treatments; self-pollination for each former cultivar and cross-pollination between them and open pollination. Four different shoots of each tree were chosen in different directions on the 
periphery of the tree. The number of clusters and the number of flowers in each cluster were counted for each shoot. All shoots were bagged before bloom stage (at balloon stage), the pollen grains for each cultivar were collected by bagged shoot at balloon stage. Self-pollination treatment was performed by bagging the shoot at the balloon stage and at full bloom the shoots were shacked to insure pollination. Hand cross pollination was made for each cultivar by using the pollen grains of both cultivars, while the open pollination with pollen grains of other cultivars represent the third treatment. The bags from the shoots of the two first treatments were removed after two weeks of full bloom stage. Normal and shotberry fruit set were recorded after 30 days from full bloom and expressed per 100 perfect inflorescence numbers. Samples of 10 inflorescence from each cultivar were taken at the full bloom stage in order to determine the number of perfect and staminate flowers and these were presented as percentage.

Pollen grains germination was examined by making germination medium consisted of $15 \%$ sucrose and 2 grams agar which were placed in Petri dishes and pollen grains for each cultivar were spread on 3 separate Petri dishes and then incubated in the incubator at $20{ }^{\circ} \mathrm{C}$ for 2 days (Pinney and Polito, 1990).

For each cultivar 3 fields from each of the 3 Petri dishes were taken, in order to determine the number of germinated pollen grains under light microscope and were presented as a percentage.

Pollen grain number for each cultivar was calculated according to Waller et al. (1998) method by using haemocytometer.

A randomize complete block design was used with 6 replicates for the pollination parts of this work while a complete randomize design was used for floral characteristic and pollen grain germination.

Data were statistically analyzed using ANOVA and Duncan's multiple range tests at 0.05 was used to compare treatments according to Steel and Torrri (1980).

\section{RESULTS AND DISCUSSION \\ 3.1. Type of flowers}

The number of perfect and staminate flowers differed from one inflorescence to another, the average percentage of these two kinds of flowers is presented in Table 1. There was no significant difference between the two cultivars in the number of the two types of flowers in the two seasons. The number of perfect flowers for the two cultivars was the same in the first season and was very close in the second one. This result indicates that this is a constant genetic characteristic and the climate conditions of no effect. The average numbers of perfect flowers depended on the inflorescence location on the shoot as Dimass et al. indicated in 1999, while Al-Kasasbeh, (2003) found that the $\%$ of perfect flowers to staminate flowers was 50.1:5.2 for Nabali Baladi while it was 91:0 and 90:5.2 for Coratina and Forontoio cultivars respectively.

\subsection{Pollen grain production}

As shown in Table 1 the number of pollen grains for Nabali Muhassan was the same during the two seasons and it was higher than the Grossa de Spagan cultivar. The average pollen grain number for Nabali Muhassan was $222250 / \mathrm{cm}^{3}$ in both seasons, while for Grossa de Spagan it respectively was $175987 / \mathrm{cm}^{3}$ and $180625 / \mathrm{cm}^{3}$ for the two seasons respectively. These results are in agreement with those of O'Rourke and Buchmann (1986) and Al-Kasasbeh, (2003) who obtained different pollen grain numbers from different cultivars.

\subsection{Pollen grain germination}

The results indicate that the germinability of pollen grains for the two cultivars was not significantly different and the mean values were close in each cultivar for the two seasons (Table 1). This finding indicates that pollen grain germinability depends on cultivar and season.

\subsection{Fruit set}

The effect of self, open (free) and cross pollination was examined in Al-Rabba Station which contains considerable number of different cultivars. This study proved that the cross pollination is necessary to obtain a good fruit set for the two studied tested cultivars in this experiment.

With Nabali Muhassan open pollination treatment significantly produced the highest fruit set percentage compared to artificial cross pollination with Grossa de Spagan and to self pollination treatments for both seasons (Table 2).

The final fruit set percentage of the former treatment was 5.66 and 3.42 in 2002 and 2003 seasons, respectively. Cross pollination of Nabali Muhassan with Grossa de Spagan increased the fruit set percentage significantly in the second season only compared to self pollination treatment. Cross pollination with Grossa de Spagan and self pollination treatment did not result in any differences between them in the final set percent of Nabali Muhassan in the first season.

With Grossa de Spagan only the open pollination treatment resulted in a significant fruit 
Table (1): Percentage of perfect and staminate flowers, pollen grain numbers and percentage of germinated pollen grains for Nabali Muhassan and Grossa de Spagan olive cultivars for two seasons.

\begin{tabular}{|c|c|c|c|c|c|c|c|c|}
\hline \multirow[b]{2}{*}{ Cultivar } & \multicolumn{4}{|c|}{ Season 2002} & \multicolumn{4}{|c|}{ Season 2003} \\
\hline & $\begin{array}{l}\% \text { of perfect } \\
\text { flowers }\end{array}$ & $\begin{array}{l}\% \text { of staminate } \\
\text { flowers }\end{array}$ & $\begin{array}{c}\text { No. of pollen } \\
\text { grains } / \mathrm{cm}^{3}\end{array}$ & $\begin{array}{c}\text { \% of germinated } \\
\text { pollen grains }\end{array}$ & $\begin{array}{l}\% \text { of perfect } \\
\text { flowers }\end{array}$ & $\begin{array}{c}\% \text { of staminate } \\
\text { flowers }\end{array}$ & $\begin{array}{c}\text { No. of pollen } \\
\text { grains } / \mathrm{cm}^{3}\end{array}$ & $\begin{array}{l}\% \text { of germinated } \\
\text { pollen grains }\end{array}$ \\
\hline Nabali Muhassan & $47.0^{a^{*}}$ & $53.0^{\mathrm{a}}$ & 222250 & $71.92^{a}$ & $41.0^{a}$ & $59.0^{\mathrm{a}}$ & 222250 & $73.5^{\mathrm{a}}$ \\
\hline Grossa de Spagan & $47.0^{\mathrm{a}}$ & 53.0 ${ }^{\mathrm{a}}$ & 175987 & $69.27^{\mathrm{a}}$ & $44.0^{\mathrm{a}}$ & $56.0^{\mathrm{a}}$ & 180625 & 71.38 \\
\hline
\end{tabular}

* Treatment means having a common letter in a column are not significantly different $(\mathrm{P}=0.05)$

Table (2): Effect of different pollination treatments on fruit set and shot berries percentage for Nabali Muhassan olive cultivar for two seasons.

\begin{tabular}{|l|c|c|c|c|}
\hline \multirow{2}{*}{ Treatments } & \multicolumn{2}{|c|}{2002 Season } & \multicolumn{2}{c|}{ 2003 Season } \\
\cline { 2 - 5 } & $\begin{array}{c}\text { Fruit set } \\
\text { percentage }\end{array}$ & $\begin{array}{c}\text { Shotberries } \\
\text { percentage }\end{array}$ & $\begin{array}{c}\text { Fruit set } \\
\text { percentage }\end{array}$ & $\begin{array}{c}\text { Shotberries } \\
\text { percentage }\end{array}$ \\
\hline Open pollination & $5.67^{\mathrm{a}} *$ & $\mathbf{0 . 0 0}^{\mathbf{a}}$ & $\mathbf{3 . 4 1 7}^{\mathrm{a}}$ & $\mathbf{0 . 0 0}^{\mathbf{c}}$ \\
\hline $\begin{array}{l}\text { Nabali Muhassan X } \\
\text { Grossa de Spagan }\end{array}$ & $1.33^{\mathrm{b}}$ & $\mathbf{3 . 1 3}^{\mathrm{b}}$ & $\mathbf{2 . 1 5}^{\mathrm{b}}$ & $\mathbf{4 . 0 1}^{\mathrm{b}}$ \\
\hline Self pollination & $\mathbf{0 . 1 5}^{\mathrm{b}}$ & $\mathbf{7 . 1 5}^{\mathrm{a}}$ & $\mathbf{0 . 1 7}^{\mathrm{c}}$ & $\mathbf{9 . 9 7}^{\mathrm{a}}$ \\
\hline
\end{tabular}

* Treatment means having a common letter in a column are not significantly different $(\mathrm{P}=0.05)$

Table (3): Effect of different pollination treatments on fruit set and shot berries for Grossa de Spagan olive cultivar for two seasons.

\begin{tabular}{|l|c|c|c|c|}
\hline \multirow{2}{*}{ Treatments } & \multicolumn{2}{|c|}{2002 Season } & \multicolumn{2}{c|}{ 2003 Season } \\
\cline { 2 - 5 } & $\begin{array}{c}\text { Fruit set } \\
\text { percentage }\end{array}$ & $\begin{array}{c}\text { Shotberries } \\
\text { percentage }\end{array}$ & $\begin{array}{c}\text { Fruit set } \\
\text { percentage }\end{array}$ & $\begin{array}{c}\text { Shot berries } \\
\text { percentage }\end{array}$ \\
\hline Open pollination & $\mathbf{8 . 8 3}^{\mathrm{a}} *$ & $\mathbf{0 . 0 0}^{\mathbf{c}}$ & $\mathbf{7 . 0 8}^{\mathrm{a}}$ & $\mathbf{0 . 0 0}^{\mathrm{b}}$ \\
\hline $\begin{array}{l}\text { Nabali Muhassan X } \\
\text { Grossa de Spagan }\end{array}$ & $\mathbf{0 . 3 9}^{\mathrm{b}}$ & $\mathbf{1 0 . 3 2}^{\mathrm{b}}$ & $\mathbf{0 . 6 7}^{\mathrm{b}}$ & $\mathbf{1 . 4 5}^{\mathrm{b}}$ \\
\hline Self pollination & $\mathbf{0 . 1 7 b}$ & $\mathbf{1 4 . 6 2 a}$ & $\mathbf{0 . 2 6 b}$ & $\mathbf{8 . 9 5 a}$ \\
\hline
\end{tabular}

* Treatment means having a common letter in a column are not significantly different $(\mathrm{P}=0.05)$ 
set compared to the other treatment, it was $8.83 \%$ and $7.58 \%$ in the two seasons respectively. Artificial cross pollination with Nabali Muhassan and self pollination treatments were not significantly different from each other in their fruit set percentage during the two years (Table 3 ).

These results are in agreement with those of Kar and Singh, (1984), Fernandez-Escopar and Gomez-Valledor; (1985), Dimassi et al. (1999); Iannotta et al. (1999); Ateyyeh et al. (2000) and Al-Kasasbeh, (2003). They indicated that many different olive cultivars produced low yield by self pollination, while open and cross pollination treatments increased fruit set percentage. AlKasasbeh, 2003 also found that open pollination resulted in a low fruit set percentage compared to cross pollination and referred this to the effect of the climate conditions and the planting system of other cultivars at the experiment location. Results in Tables 2 and 3 indicate that the self pollination treatment produced significantly high percentage of shotberries compared to open pollination for both cultivars during the two successive years of this study. These results are in agreement with the previous studies (Lavee and Datt, 1978, Fernandez-Escopar and Gomez-Valledor, 1985 and Al-Kasasbeh, 2003).

\section{DISCUSSION}

The results of this experiment indicated that open pollination was more efficient than hand (artificial) cross pollination. Under the condition of this study hand cross pollination was not efficient to improve the fruit set except for one treatment in one year ( Nabali Muhassan, 2003 season).

Self pollination resulted in the lowest fruit set percentage. The open and cross pollination had higher fruit set percentage compared to self pollination due to a higher level of fertilization (Griggs et al., 1975, Lavee and Datt, 1978, and Fernandez-Escopar and Gomez-Valledor, 1985). In the self pollination treatment the percentage of shotberries was the highest because of low fertilization.

Nabali Muhassan and Grossa de Spagan can be considered as a partial self-incompatible cultivars and they are not good pollinizers for each other under the condition of the study. This might explain why free pollination was usually more efficient than artificial cross pollination. These results suggest that these two olive cultivars should not be planted as an individual cultivar in any orchard. It should be planted with other olive cultivars to accomplish open pollination under South Jordan environment conditions.

\section{REFERENCES}

Al-Kasasbeh M. F. (2003). A study of self and cross-compatibility of three olive cultivars in Jordan. M.Sc. Thesis, University of Jordan, Amman-Jordan.

Ateyyeh A., Stoesser R. and Qrunfleh M. (2000). Reproduction biology of the olive (Olea europaea L.) cultivar Nabali Baladi. Journal of Applied Botany.74, 255-27.

Badr S. A. and Hartmann H. T. (1971). Effect of diurnally fluctuating vs. constant temperature on flower induction and sex expression in the olive. Physiol. Plant, 24, 40-45.

Brooks R. M. (1948). Seasonal incidence of perfect and staminate olive flowers. Proc. Amer. Soc. Hort. Sci. 52, 213-218.

Cuevas J. and Polito V.S. (1997). Compatibility relationships in 'Manzanillo' olive. Hort. Science, 32(6): 1056-1058.

Cuevas J. and Rallo L. (1990). Respones to crosspollination in olive trees with different levels of flowering. Acta. Hort. 286: 179182.

Cuevas J., Pinny K. and Polito V.S. (1999). Flower differentiation, pistil development and pistil abortion in olive (Olea europaea L.) 'Manzanillo'.Acta. Hort., 474, 293-296.

Daoud A. D. (1997). A study on flowering, pollination and fruit set of some olive cultivars. Iraqi Agri. J. 2(1): 51-64.

Dimass K., Therios I. and Balatsos A. (1999). The blooming period and self-fruit fullness in twelve Greek and three foreign cultivars. Acta Hort. 474: 275-278.

FAO (2000). Faostat Database Gateway. From Http:// apps.Fao.org.

Fernandez-Escopar R. and Gomez-Valledor G. (1985). Cross-pollination in 'Gordal Sevillano' olives. Hort. Science. 20 (2):191192.

Griggs W. H., Hartmann H. T., Bradley M. V., Iwakiri B. T. and Whisler J. E. (1975). Olive pollination in California. Cal. Agr. Exp. Sta. Bull. 869:141-156.

Hartmann H. T. and Panetssos C. (1961). Effect of soil moisture deficiency during floral development on fruit fullness in olives. Proc. Amer. Soc. Hort. Sci. 78: 209-217.

Hechimi M. and Raoudha K. (1995). Floral biology of the olive: the problem of self- 
incompatibility in Meski variety and search for pollinizers. Olivae. 55: 35-39.

Ionnotta N., Peri L. and Zaffina F. (1999). The influence of different types of treatments on fruit set in the Carolea cultivar (Olea europaea L.). Acta. Hort. 474: 313-315.

Kar P. L. and Singh R. P. (1984). Pollination and compatibility studies in some olive cultivars. Himachal Journal of Agricultureal Research. 10(1): 55-57.

Lavee S. and Datt Z. (1978). The necessity of cross-pollination for fruit set of 'Manzanillo' olives. J. Hort. Sci. 53(4): 261266.

Noro K. (1926). Further studies on the staminiferous flowers of the olive tree with special reference to the realation of nutrition to the staminiferous flower. Scient. Agrric. Soc. Jour. of Japan. No. 289.

O’Rourke M. K. and Buchmann S. L. (1986). Pollen yield from olive tree cvs. Manzanillo and Swan Hill in urban environment. J. Amer. Soc. Hort. Sci. 111(6): 980-984.

Pinney K. and Polito V.S. (1990). Olive pollen storage and in vitro germination. Acta Hort. 286: 207-211.
Rapoport H. F. and Rallo L. (1990). Ovule development in normal and parthenocarpic olive fruits. Acta Hort. 286:223-226.

Salman M. A. (1992). Characters of some local and foreign olive ( Olea europaea L.). (Abstract). Iraqi Journal of Agricultural Research. 2(1): 56-58.

Shatat F. and Sawwan J. (1986). Effect of inflorescence position on the tree and on shoots on flower development and flower type in the olive. Dirasat.11(2): 171-185.

Steel R. G. and Torrie J. H. (1980). Principles and procedures of statistics. $2^{\text {nd }} \mathrm{Ed}$. Mc GrawHill Book Company.

Ugrinovic K. and Stampar F. (1996). Fertilization of olive ( Olea europaea L.) cultivars Istrsk belica, Pendolino and Leccino by different pollinators. (Abstract). Kmetijstvo. 67:183188.

Uriu, K. (1959). Periods of pistil abortion development of the olive flower. Proc. Amer. Soc. Hort. Sci. 73, 194-202.

Waller J. M., Ritchie B.J., and Holderness M. (1998). Plant Clinic Handbook. Information Press. U. K.

$$
\begin{aligned}
& \text { دراسة طبيعة الازهار والتلقيح وعقد الثمار لصنفين من الزيتون في جنوب الاردن } \\
& \text { علاء عبدالرزاق الجميلي - رائد لطقي احمد* }
\end{aligned}
$$

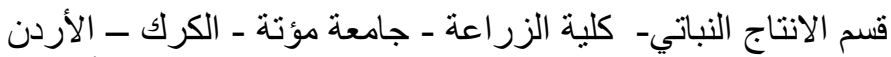

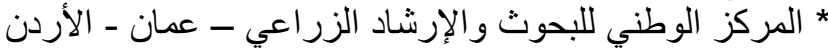

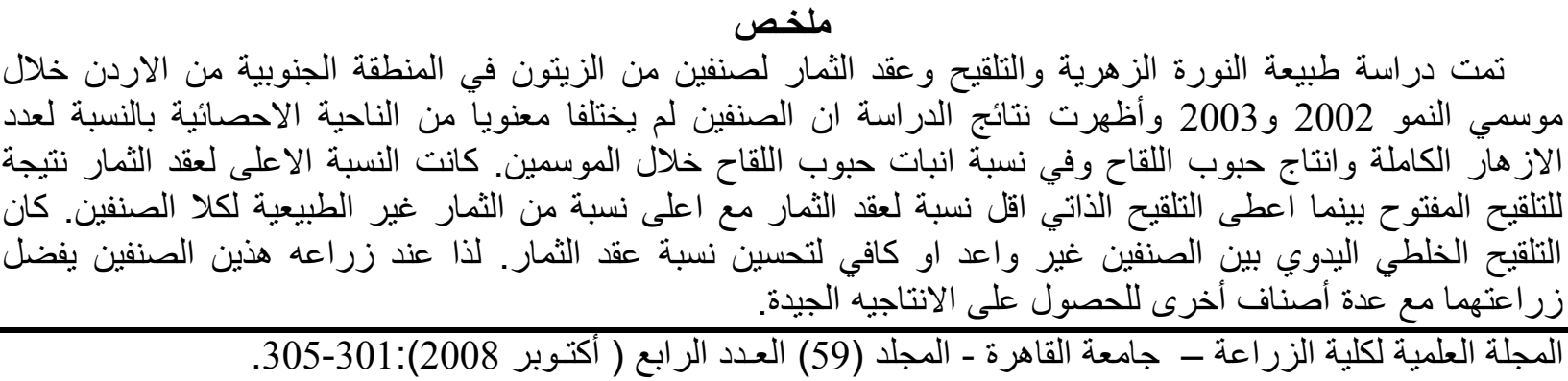

